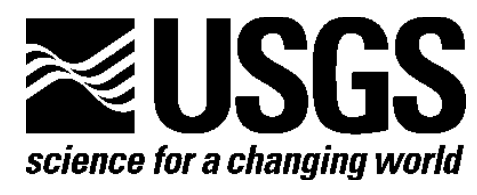

\title{
Estimate of Tephra Accumulation Probabilities for the U.S. Department of Energy's Hanford Site, Washington
}

Open-File Report 2011-1064

U.S. Department of the Interior U.S. Geological Survey 


\section{Estimate of Tephra Accumulation Probabilities for the U.S. Department of Energy's Hanford Site, Washington}

By Richard P. Hoblitt and William E. Scott

Open-File Report 2011-1064

U.S. Department of the Interior

U.S. Geological Survey 


\section{U.S. Department of the Interior \\ KEN SALAZAR, Secretary}

\section{U.S. Geological Survey \\ Marcia K. McNutt, Director}

U.S. Geological Survey, Reston, Virginia 2011

For product and ordering information:

World Wide Web: http://www.usgs.gov/pubprod

Telephone: 1-888-ASK-USGS

For more information on the USGS—-the Federal source for science about the Earth, its natural and living resources, natural hazards, and the environment:

World Wide Web: http://www.usgs.gov

Telephone: 1-888-ASK-USGS

Suggested citation:

Hoblitt, R.P., and Scott, W.E., 2011, Estimate of tephra accumulation probabilities for the U.S. Department of Energy's Hanford Site, Washington: U.S. Geological Survey Open-File Report 2011-1064, 15 p. [http://pubs.usgs.gov/of/2011/1064/].

Any use of trade, product, or firm names is for descriptive purposes only and does not imply endorsement by the U.S. Government.

Although this report is in the public domain, permission must be secured from the individual copyright owners to reproduce any copyrighted material contained within this report. 


\section{Contents}

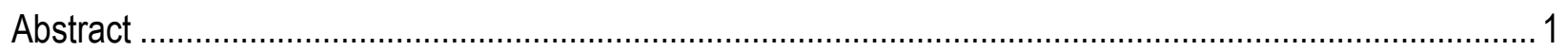

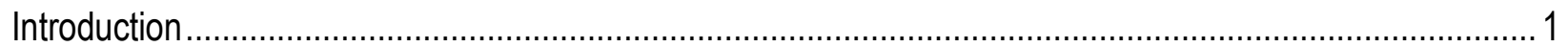

Potential Tephra Sources and Eruption Magnitudes.......................................................................

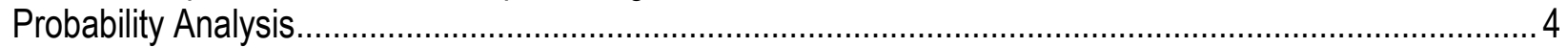

$P(1)$ : Annual Probability of Eruption ................................................................................................

$P(2 \mid 1)$ : Mean Probability of Wind Direction ....................................................................................

$P(3 \mid 2)$ : Exceedance Probability of Tephra Accumulation ...................................................................

$\mathrm{P}(1$ and 2 and 3$)$ : Estimate of Tephra Thickness that would be Equaled or Exceeded at the $1 \times 10^{-4}$ Annual Probability Level ..................................................................................

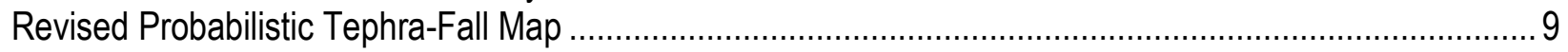

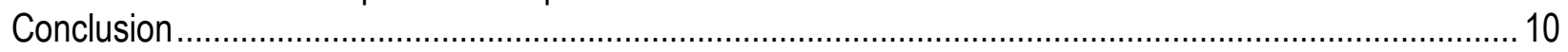

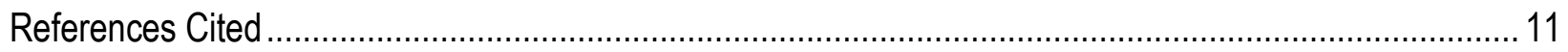

Appendix 1. Discussion of Table 1 Highlighting Differences in Eruptive History Details from

Compilations by Hoblitt and Others (1987) and Siebert and Others (2010) ................................... 14

Appendix 2. Tephra Data Used in Estimation of Annual Exceedance Probabilities ................................... 15

\section{Figures}

1. Annual probability of exceedance for tephra fallout (in centimeters) at the Hanford Site in south-central Washington State.

2. Preliminary probabilistic tephra hazard map for Pacific Northwest revised from Hoblitt and others (1987) and Scott and others (1995).

\section{Tables}

1. Mean annual probabilities of substantial ( $\geq 0.1 \mathrm{~km}^{3}$ bulk volume) explosive eruptions of tephra from the major Cascade volcanic centers in the U.S. and Canada (first three centers).

2. Average wind directions (direction that the wind is blowing toward) in $16,22.5^{\circ}$-sectors for nine altitude ranges (in kilometers) for Quillayute, Washington, from January 1, 1973, through June 30, 2010 .

3. Exceedance probabilities of tephra accumulations at $200 \mathrm{~km}$ distance from source volcano for 14 VEl 4 and 5 eruptions from the global catalog (Appendix 2; Newhall and Hoblitt, 2002). ............... 7

4. Exceedance probabilities and annual probabilities of exceedence of tephra accumulations at the Hanford Site for the eruption data from table 3. 
Conversion Factors

\begin{tabular}{|c|c|c|}
\hline Multiply & By & To obtain \\
\hline \multicolumn{3}{|c|}{ Length } \\
\hline centimeter $(\mathrm{cm})$ & 0.3937 & inch (in.) \\
\hline millimeter (mm) & 0.03937 & inch (in.) \\
\hline meter $(\mathrm{m})$ & 3.281 & foot $(\mathrm{ft})$ \\
\hline kilometer (km) & 0.6214 & mile (mi) \\
\hline kilometer (km) & 0.5400 & mile, nautical (nmi) \\
\hline meter $(\mathrm{m})$ & 1.094 & yard (yd) \\
\hline \multicolumn{3}{|c|}{ Area } \\
\hline square centimeter $\left(\mathrm{cm}^{2}\right)$ & 0.001076 & square foot $\left(\mathrm{ft}^{2}\right)$ \\
\hline square meter $\left(\mathrm{m}^{2}\right)$ & 10.76 & square foot $\left(\mathrm{ft}^{2}\right)$ \\
\hline square centimeter $\left(\mathrm{cm}^{2}\right)$ & 0.1550 & square inch $\left(\mathrm{ft}^{2}\right)$ \\
\hline square kilometer $\left(\mathrm{km}^{2}\right)$ & 0.3861 & square mile $\left(\mathrm{mi}^{2}\right)$ \\
\hline \multicolumn{3}{|c|}{ Volume } \\
\hline cubic meter $\left(\mathrm{m}^{3}\right)$ & 264.2 & gallon (gal) \\
\hline cubic decimeter $\left(\mathrm{dm}^{3}\right)$ & 0.2642 & gallon (gal) \\
\hline cubic meter $\left(\mathrm{m}^{3}\right)$ & 0.0002642 & million gallons (Mgal) \\
\hline cubic centimeter $\left(\mathrm{cm}^{3}\right)$ & 0.06102 & cubic inch $\left(\right.$ in $\left.^{3}\right)$ \\
\hline cubic decimeter $\left(\mathrm{dm}^{3}\right)$ & 61.02 & cubic inch $\left(\right.$ in $\left.^{3}\right)$ \\
\hline liter $(\mathrm{L})$ & 61.02 & cubic inch $\left(\mathrm{in}^{3}\right)$ \\
\hline cubic decimeter $\left(\mathrm{dm}^{3}\right)$ & 0.03531 & cubic foot $\left(\mathrm{ft}^{3}\right)$ \\
\hline cubic meter $\left(\mathrm{m}^{3}\right)$ & 35.31 & cubic foot $\left(\mathrm{ft}^{3}\right)$ \\
\hline cubic meter $\left(\mathrm{m}^{3}\right)$ & 1.308 & cubic yard $\left(\mathrm{yd}^{3}\right)$ \\
\hline cubic kilometer $\left(\mathrm{km}^{3}\right)$ & 0.2399 & cubic mile $\left(\mathrm{mi}^{3}\right)$ \\
\hline \multicolumn{3}{|c|}{ Mass } \\
\hline $\operatorname{gram}(\mathrm{g})$ & 0.03527 & ounce, avoirdupois (oz) \\
\hline kilogram (kg) & 2.205 & pound avoirdupois (lb) \\
\hline megagram (Mg) & 1.102 & ton, short $(2,000 \mathrm{lb})$ \\
\hline megagram $(\mathrm{Mg})$ & 0.9842 & ton, long $(2,240 \mathrm{lb})$ \\
\hline \multicolumn{3}{|c|}{ Density } \\
\hline kilogram per cubic meter $\left(\mathrm{kg} / \mathrm{m}^{3}\right)$ & 0.06242 & pound per cubic foot $\left(\mathrm{lb} / \mathrm{ft}^{3}\right)$ \\
\hline gram per cubic centimeter $\left(\mathrm{g} / \mathrm{cm}^{3}\right)$ & 62.4220 & pound per cubic foot $\left(\mathrm{lb} / \mathrm{ft}^{3}\right)$ \\
\hline
\end{tabular}




\title{
Estimate of Tephra Accumulation Probabilities for the U.S. Department of Energy's Hanford Site, Washington
}

\author{
By Richard P. Hoblitt and William E. Scott
}

\begin{abstract}
In response to a request from the U.S. Department of Energy, we estimate the thickness of tephra accumulation that has an annual probability of 1 in 10,000 of being equaled or exceeded at the Hanford Site in south-central Washington State, where a project to build the Tank Waste Treatment and Immobilization Plant is underway. We follow the methodology of a 1987 probabilistic assessment of tephra accumulation in the Pacific Northwest. For a given thickness of tephra, we calculate the product of three probabilities: (1) the annual probability of an eruption producing $0.1 \mathrm{~km}^{3}$ (bulk volume) or more of tephra, (2) the probability that the wind will be blowing toward the Hanford Site, and (3) the probability that tephra accumulations will equal or exceed the given thickness at a given distance. Mount St. Helens, which lies about $200 \mathrm{~km}$ upwind from the Hanford Site, has been the most prolific source of tephra fallout among Cascade volcanoes in the recent geologic past and its annual eruption probability based on this record (0.008) dominates assessment of future tephra falls at the site. The probability that the prevailing wind blows toward Hanford from Mount St. Helens is 0.180 . We estimate exceedance probabilities of various thicknesses of tephra fallout from an analysis of 14 eruptions of the size expectable from Mount St. Helens and for which we have measurements of tephra fallout at $200 \mathrm{~km}$. The result is that the estimated thickness of tephra accumulation that has an annual probability of 1 in 10,000 of being equaled or exceeded is about 10 centimeters. It is likely that this thickness is a maximum estimate because we used conservative estimates of eruption and wind probabilities and because the 14 deposits we used probably provide an overestimate. The use of deposits in this analysis that were mostly compacted by the time they were studied and measured implies that the bulk density of the tephra fallout we consider here is in the range of $1,000-1,250 \mathrm{~kg} / \mathrm{m}^{3}$. The load of 10 $\mathrm{cm}$ of such tephra fallout on a flat surface would therefore be in the range of $100-125 \mathrm{~kg} / \mathrm{m}^{2}$; addition of water from rainfall or snowmelt would provide additional load.
\end{abstract}

\section{Introduction}

The following analysis re-examines the results of a probabilistic assessment of tephra accumulation in the Pacific Northwest that was part of a U.S. Geological Survey (USGS) report for the Nuclear Regulatory Commission published in 1987 (Hoblitt and others, 1987). In 2010, U.S. Department of Energy, Office of River Protection, Richland, Washington, contacted the USGS regarding tephra hazards and design of the new Hanford Tank Waste Treatment and Immobilization Plant (referred to hereafter as the Waste Treatment Plant), which is under construction at the Department's Hanford Site in south-central Washington State. We were also contacted by the Defense Nuclear Facilities Safety Board, which is reviewing the design. During a conference call with these parties on August 18, 2010, we agreed to revisit the subject of tephra hazards for the new facility. The specific subject of interest was an estimate of the thickness of tephra accumulation that would have an annual exceedance probability of $1 \times 10^{-4}$; that is, the thickness of tephra accumulation that would have 
an annual probability of 1 in 10,000 of being equaled or exceeded. Our approach largely follows that of the 1987 report, but with some additional data and topics.

\section{Potential Tephra Sources and Eruption Magnitudes}

Of the 16 major volcanic centers in the U.S. and Canadian Cascades volcanic arc, 14 have erupted since the disappearance of ice age glaciers about 12,000-15,000 years ago; only Mount Cayley and Mount Jefferson have been quiet (Scott, 1990; Hildreth, 2007). During this time period, three have produced substantial volumes (defined here as a bulk erupted volume of $\geq 0.1 \mathrm{~km}^{3}$ ) of tephra fallout on multiple occasions, seven have produced one such event, and six have not produced such tephra fallout. Hoblitt and others (1987) determined mean annual probabilities of a substantial explosive eruption at U.S. Cascade centers on the basis of the data in table 1 (modified slightly by additional information and the inclusion of Canadian centers; appendix 1).

Table 1. Mean annual probabilities of substantial ( $\geq 0.1 \mathrm{~km}^{3}$ bulk volume) explosive eruptions of tephra from the major Cascade volcanic centers in the United States and Canada (first three centers).

[U.S. data slightly modified from Hoblitt and others (1987) as described in appendix 1, which also explains differences with a recent compilation of worldwide data by Siebert and others (2010). Canadian data from Hildreth (2007) and Siebert and others (2010); wind data from table 2. All volcanoes with no substantial eruptions are assigned a default value of $1 \times 10^{-5}$.]

\begin{tabular}{|c|c|c|c|c|c|}
\hline Volcano & $\begin{array}{c}\text { Time } \\
\text { interval } \\
\text { (yr) }\end{array}$ & $\begin{array}{l}\text { Explosive } \\
\text { eruptions } \\
\geq 0.1 \mathrm{~km}^{3}\end{array}$ & $\begin{array}{c}\text { Mean } \\
\text { annual } \\
\text { probability }\end{array}$ & $\begin{array}{l}\text { Distance and } \\
\text { azimuth from } \\
\text { volcano to } \\
\text { Hanford } \\
\text { (km) }\end{array}$ & $\begin{array}{c}\text { Average } \\
\text { probability of wind } \\
\text { from azimuth } \\
\text { direction (3-18 km } \\
\text { altitude) }\end{array}$ \\
\hline Mount Meager & 12,000 & 1 & $8 \times 10^{-5}$ & $550 \mathrm{SE}$ & 0.10 \\
\hline Mount Cayley & 12,000 & 0 & $1 \times 10^{-5}$ & $490 \mathrm{SE}$ & 0.10 \\
\hline Mount Garibaldi & 12,000 & 0 & $1 \times 10^{-5}$ & $450 \mathrm{SE}$ & 0.10 \\
\hline Mount Baker & 12,000 & 1 & $8 \times 10^{-5}$ & $300 \mathrm{SE}$ & 0.10 \\
\hline Glacier Peak & 13,000 & 3 & $2 \times 10^{-4}$ & $210 \mathrm{SE}$ & 0.10 \\
\hline Mount Rainier & 10,000 & 1 & $1 \times 10^{-4}$ & $175 \mathrm{E}$ & 0.17 \\
\hline Mount St. Helens & 15,000 & 12 & $8 \times 10^{-4}$ & $210 \mathrm{E}$ & $0.18^{1}$ \\
\hline $\begin{array}{l}\text { Mount St. Helens } \\
\text { (Spirit Lake stage) }\end{array}$ & 4500 & 9 & $2 \times 10^{-3}$ & $210 \mathrm{E}$ & $0.18^{1}$ \\
\hline $\begin{array}{l}\text { Mount St. Helens } \\
\text { (recent cluster) }\end{array}$ & 500 & 4 & $8 \times 10^{-3}$ & $210 \mathrm{E}$ & $0.18^{1}$ \\
\hline Mount Adams & 12,000 & 0 & $1 \times 10^{-5}$ & $155 \mathrm{ENE}$ & 0.18 \\
\hline Mount Hood & 15,000 & 0 & $1 \times 10^{-5}$ & $210 \mathrm{NE}$ & 0.14 \\
\hline Mount Jefferson & 15,000 & 0 & $1 \times 10^{-5}$ & $270 \mathrm{NE}$ & 0.14 \\
\hline Three Sisters & 12,000 & 1 & $8 \times 10^{-5}$ & $325 \mathrm{NNE}$ & 0.07 \\
\hline Newberry Volcano & 10,000 & 1 & $1 \times 10^{-4}$ & $340 \mathrm{NNE}$ & 0.07 \\
\hline $\begin{array}{l}\text { Crater Lake } \\
\text { (Mount Mazama) }\end{array}$ & 12,000 & 3 & $3 \times 10^{-4}$ & $450 \mathrm{NNE}$ & 0.07 \\
\hline Medicine Lake volcano & 11,000 & 1 & $9 \times 10^{-5}$ & $590 \mathrm{NNE}$ & 0.07 \\
\hline Mount Shasta & 10,000 & 1 & $1 \times 10^{-4}$ & $620 \mathrm{NNE}$ & 0.07 \\
\hline Lassen volcanic center & 11,000 & 0 & $1 \times 10^{-5}$ & $700 \mathrm{NNE}$ & 0.07 \\
\hline
\end{tabular}

${ }^{1}$ Value for Mount St. Helens from Hanford sector in table 2 
Because composite volcanoes such as those in the Cascades typically have episodes of more frequent activity for centuries to millennia alternating with apparently dormant intervals of roughly similar duration (for example, Crandell and Mullineaux, 1978; Crandell and others, 1979; Nathenson and others, 2007), the mean annual eruption probability can vary greatly depending on the time span selected. As shown in table 1, the eruption probability for Mount St. Helens, based on the average frequency of events during three time periods, ranges from $8 \times 10^{-4}$ for the past 15,000 years (which includes a dormant interval of about 7,000 years) to $2 \times 10^{-3}$ for the past 4,500 years (which includes several dormant intervals of 300-600 years) to $8 \times 10^{-3}$ for the past 500 years (which includes two dormant intervals of 50-100 years). Mount St. Helens is the only Cascade center that one could argue strongly is in a period of increased eruptive frequency; thus we use $8 \times 10^{-3}$ in the following analysis.

Five Cascade volcanic centers lie less than or close to $200 \mathrm{~km}$ of the Hanford Site and, except for Glacier Peak, lie at azimuths that have the highest probabilities $(0.14-0.18)$ of being upwind. Glacier Peak and St. Helens have produced more than one substantial explosive eruption in the recent geologic past, Rainier one, and Adams and Hood none. A brief summary of each center follows.

- Glacier Peak produced three large explosive eruptions in a brief time period shortly after the end of the last ice age, two of which deposited widespread tephra over eastern Washington (Gardner and others, 1998; Kuehn and others, 2009). Since then eruptive activity has consisted chiefly of lava dome extrusion and collapse accompanied by modest tephra production (Begét, 1982, 1983).

- Mount Rainier has produced numerous eruptions of lava flows accompanied by modest explosive eruptions during the past 10,000 years, but only one substantial explosive eruption, which deposited pumice and ash over the eastern flank of the volcano about 2,200 years ago (Hoblitt and others, 1998; Sisson and Vallance, 2009). That event produced about $7.5 \mathrm{~cm}$ of tephra fallout at a distance of $25 \mathrm{~km}$ from the vent; the distal extent of this tephra is poorly known, but probably no more than a few millimeters fell at $200 \mathrm{~km}$.

- Mount St. Helens has been the most prolific source of substantial explosive eruptions and accompanying tephra fallout in the Cascades since the end of the last ice age. As discussed above, the volcano has produced four significant explosive eruptions during the past 500 years (Hoblitt and others 1980; Carey and others, 1995; Mullineaux, 1996). These and a few older St. Helens eruptions have been studied in great detail and provide some of the most robust thickness-distance data in the world-wide sample analyzed in this report (appendix 2).

- Mounts Hood and Adams have not produced substantial explosive eruptions or widespread tephra layers during their $\sim 500,000$-year lifespans. Effusion of lava flows (Adams) and lava domes (recent history of Hood) accompanied by modest tephra production have characterized these volcanoes (Hildreth and Fierstein, 1997; Scott and others, 1997).

The rest of the Cascade centers lie 300-700 km from Hanford, are at less probable wind azimuths, and have low $\left(10^{-4}-10^{-5}\right)$ annual probabilities of producing a substantial explosive eruption.

On rare occasions during the past 1 million years, a few Cascade centers produced voluminous tephra eruptions measuring tens of cubic kilometers. Some of these eruptions are known to have been accompanied by caldera collapse. The most recent such event occurred about 7,700 years ago at Mount Mazama and created Crater Lake caldera; about $30 \mathrm{~cm}$ of tephra fell $500 \mathrm{~km}$ from the vent along the axis of deposition (northeast). Other such events near Mount Baker ( $\sim 1$ million years ago) and near Lassen Peak (610,000 years ago) are thought to have been of similar size (Hildreth, 2007). Studies of the Mazama system conclude that a volume of shallow silicic magma capable of producing another caldera-forming eruption will not accumulate for thousands of years (Bacon and others, 1997). From the nature of their eruptions over the past few thousand years, St. Helens, Rainier, Adams, and Hood are 
judged incapable of such activity (Hildreth, 2007). No other Cascade system is suspected to be primed to produce tens of cubic kilometers of tephra in a caldera-forming eruption during the next few centuries to millennia, so the annual probability of such an event appears negligible $\left(\sim 3 \times 10^{-6}\right)$.

The following discussion refers to the Volcanic Explosivity Index (VEI; Newhall and Self, 1982), a scale analogous to the magnitude scale for earthquakes. VEI is chiefly a function of bulk erupted volume and height of the eruption cloud. Only eruptions greater than VEI $3\left(0.01-0.1 \mathrm{~km}^{3}\right)$ are capable of producing more than a millimeter of fallout at a distance of $200 \mathrm{~km}$ from a vent (table 3 in Newhall and Hoblitt, 2002). Cascade eruptions of the recent geologic past referred to as substantial (capable of producing centimeters or more of fallout at $200 \mathrm{~km})$ include VEI $4\left(0.1-1.0 \mathrm{~km}^{3}\right.$; typically called large), $5\left(1-10 \mathrm{~km}^{3}\right.$; very large), and $6\left(10-100 \mathrm{~km}^{3}\right)$ events. As discussed above, the probability of a Cascade eruption in the high range of VEI 6 or larger in the near future is negligible, so such events are not considered in the following analysis. On average, VEI 4 eruptions have an annual global probability of about 0.5 - one about every 2 years; VEI 5 eruptions about 0.08 - a little less than one per decade (fig. 2 in Newhall and Hoblitt, 2002).

The deposits of tephra falls analyzed in this report (appendix 2) are chiefly from a compilation by Newhall and Hoblitt (2002) that was used to develop a generic event-tree technique for forecasting the outcome of volcanic unrest and eruption. They used a worldwide dataset from 86 historical and prehistoric eruptions of VEI 4-8 to estimate exceedance probabilities of tephra-fall thickness at distances out to $200 \mathrm{~km}$ from the source volcano. We use a subset of 13 VEI 4 to 5 events from this compilation for which there exist measurements of fallout thickness at $200 \mathrm{~km}$ from the volcano, the approximate distance from Mount St. Helens to the Hanford Site. We add a fourteenth event by including measurements of tephra fallout at $200 \mathrm{~km}$ for the 1982 eruption of El Chichón, Mexico, (Varecamp and others, 1984) to the more proximal measurements given in Newhall and Hoblitt (2002).

Two of the events we include have been categorized elsewhere as VEI 6. The largest known eruption of St. Helens is the Yn eruption, which occurred about 3,800 years ago (Mullineaux, 1996). This eruption is categorized in the Smithsonian Institution's global catalog as VEI 6 (Siebert and others, 2010), but at most on the low end of the VEI 6 range, or about $15 \mathrm{~km}^{3}$ (Carey and others, 1995; Gardner and others, 1998). Similarly, the 1991 eruption of Mount Pinatubo is listed as VEI 6 (Siebert and others, 2010). However, the fallout deposit itself from that eruption probably ranks as VEI 5 (PaladioMelosantos and others, 1996; Scott and others, 1996).

\section{Probability Analysis}

The annual probability of a given thickness of tephra accumulation from a given volcano at a given point is the product of three probabilities (Hoblitt and others, 1987):

1. The marginal probability that the volcano will produce an eruption of a given magnitude in a given year, $\mathrm{P}(1)$;

2. The conditional probability that the wind will blow from the volcano toward the given point, $\mathrm{P}(2 \mid 1)$; and

3. The conditional probability that the eruption will deposit as much or more than the given thickness at the distance in question, $\mathrm{P}(3 \mid 2)$.

The probability we seek is $\mathrm{P}(1$ and 2 and 3$)=\mathrm{P}(1) * \mathrm{P}(2 \mid 1) * \mathrm{P}(3 \mid 2)$.

Because the probability of more than one regional volcano becoming active in a given year is exceedingly small, the probabilities from individual volcanoes are effectively mutually exclusive. Thus the total annual probability will be the sum of the probabilities from each volcano in the region. 
For the Hanford Waste Treatment Plant, we focus solely on Mount St. Helens. Decades of geological study have shown that St. Helens has a propensity for frequent large explosive eruptions; a propensity that is unusual even in a global context. As discussed above, other regional volcanoesAdams, Hood, Rainier, Glacier Peak, and Jefferson-do not contribute significantly to the total probability because of low eruption probabilities, low explosivities, greater distances from Hanford, less favorable azimuths, or combinations thereof (table 1).

\section{$P(1)$ : Annual Probability of Eruption}

St. Helens has been particularly active in the past approximately 500 years (table 1). During this interval it produced four large or very large (VEI 4-5) eruptions (Hoblitt and others, 1980; Carey and others, 1995; Mullineaux, 1996): May 18, 1980; 1800 CE, T tephra; 1482 CE, We tephra; and 1480 CE, Wn tephra. This results in a mean annual probability of a VEI 4-5 eruption of 0.008.

A group of USGS physical volcanologists gathered at the Cascades Volcano Observatory (CVO) on August 26, 2010, to discuss St. Helens' current eruption probability. On a global basis, it is known that eruption frequency varies inversely with eruption magnitude- $-\mathrm{VEI}_{\mathrm{n}-1}$ is about 6 times more probable than $\mathrm{VEI}_{\mathrm{n}}$ (Newhall and Hoblitt, 2002). From this one may posit that volcanoes have a gestation period during which they accumulate a sufficient volume of gas-charged magma to trigger an explosive eruption. Most volcanologists agree with this hypothesis, and it is almost certainly true for some, perhaps most, volcanoes. Following this line of reasoning, the probability of a large explosive eruption decreases precipitously immediately after such an event. Some volcanologists at CVO argued that St. Helens' explosive eruption probability is currently diminished because of a very large explosive eruption just three decades ago. There are two problems with this argument. First, there is a clear violation of the reduced eruption probability argument in the data for St. Helens itself - the We eruption occurred only two years after the Wn eruption. Second, even if the eruption probability is reduced, how do we quantify it? To be conservative in this analysis, we will retain the original estimate of St. Helens' mean annual eruption probability, that is, $\mathrm{P}(1)=0.008$.

\section{$P(2 \mid 1)$ : Mean Probability of Wind Direction}

To update the wind-direction probabilities used in an earlier report (Hoblitt and others, 1987; which used data in the 3-16 km altitude range), additional upper-air sounding data for Quillayute, Washington, were obtained from the National Climate Data Center. The Quillayute station has a long data record that is considered representative of the region. The dataset begins on January 1, 1973, and ends on June 30, 2010 - a period of 13,694 days, or about 37.5 years. Soundings are typically taken twice daily. Many soundings were unsuitable for analysis because they contained untrustworthy or corrupted data, and many were unsuitable for specific altitude ranges because they did not extend to sufficiently high altitudes.

Aside from the first data point, which is taken at ground level, data are collected at height intervals that vary during each sounding, and from one sounding to the next. Consequently, to obtain wind azimuth estimates at specified altitudes it is necessary to interpolate using bracketing data points. This provided the upper and lower limiting values for data series. To deal with discontinuity at 0/360 degrees, we used the method of Mitsuta (Mori, 1986) to transform the wind directions before averaging. The data series were numerically integrated over the specified altitude range using the trapezoidal rule and divided by the altitude range to obtain an average wind direction for a given sounding. Average wind directions for individual soundings were sorted into sixteen 22.5-degree bins. Results are given in table 2 . 
Table 2. Average wind directions (direction that the wind is blowing toward) in sixteen $22.5^{\circ}$-sectors for nine altitude ranges (in kilometers) for Quillayute, Washington, from January 1, 1973, through June 30, 2010.

[Hanford row is a $22.5^{\circ}$ sector centered on an azimuth of $80^{\circ}$ - the approximate azimuth of Hanford from Mount St. Helens. The maximum value for the Hanford sector, 0.180 in the $3-18 \mathrm{~km}$ range, is used in exceedance calculations. Num., number of observations]

\begin{tabular}{|c|c|c|c|c|c|c|c|c|c|}
\hline & \multicolumn{9}{|c|}{ Altitude Range, in kilometers } \\
\hline & 3 to 6 & 3 to 9 & 3 to 12 & 3 to 15 & 3 to 18 & 3 to 21 & 3 to 24 & 3 to 27 & 3 to 30 \\
\hline $\mathbf{N}$ & 0.056 & 0.051 & 0.048 & 0.035 & 0.033 & 0.035 & 0.047 & 0.069 & 0.096 \\
\hline NNE & 0.100 & 0.096 & 0.085 & 0.079 & 0.071 & 0.076 & 0.083 & 0.092 & 0.081 \\
\hline NE & 0.141 & 0.133 & 0.134 & 0.135 & 0.138 & 0.124 & 0.111 & 0.079 & 0.060 \\
\hline ENE & 0.148 & 0.152 & 0.154 & 0.172 & 0.179 & 0.173 & 0.130 & 0.091 & 0.062 \\
\hline $\mathbf{E}$ & 0.133 & 0.143 & 0.151 & 0.162 & 0.174 & 0.169 & 0.141 & 0.117 & 0.093 \\
\hline ESE & 0.119 & 0.127 & 0.127 & 0.139 & 0.144 & 0.142 & 0.138 & 0.131 & 0.109 \\
\hline SE & 0.093 & 0.097 & 0.096 & 0.097 & 0.098 & 0.101 & 0.117 & 0.129 & 0.130 \\
\hline SSE & 0.064 & 0.063 & 0.061 & 0.063 & 0.062 & 0.063 & 0.078 & 0.104 & 0.108 \\
\hline $\mathbf{S}$ & 0.042 & 0.042 & 0.048 & 0.043 & 0.034 & 0.041 & 0.046 & 0.061 & 0.077 \\
\hline SSW & 0.026 & 0.023 & 0.025 & 0.022 & 0.019 & 0.020 & 0.029 & 0.033 & 0.044 \\
\hline SW & 0.013 & 0.013 & 0.014 & 0.012 & 0.009 & 0.009 & 0.013 & 0.015 & 0.020 \\
\hline WSW & 0.010 & 0.009 & 0.010 & 0.007 & 0.009 & 0.008 & 0.009 & 0.011 & 0.015 \\
\hline $\mathbf{W}$ & 0.009 & 0.009 & 0.008 & 0.007 & 0.007 & 0.006 & 0.008 & 0.008 & 0.009 \\
\hline WNW & 0.009 & 0.008 & 0.008 & 0.006 & 0.006 & 0.006 & 0.008 & 0.009 & 0.012 \\
\hline NW & 0.013 & 0.012 & 0.009 & 0.008 & 0.007 & 0.010 & 0.014 & 0.017 & 0.022 \\
\hline NNW & 0.025 & 0.024 & 0.021 & 0.014 & 0.012 & 0.017 & 0.028 & 0.034 & 0.061 \\
\hline Hanford & 0.144 & 0.149 & 0.152 & 0.164 & 0.180 & 0.175 & 0.141 & 0.105 & 0.073 \\
\hline Num. & 15976 & 15007 & 14033 & 13574 & 13110 & 12259 & 11082 & 8511 & 3607 \\
\hline
\end{tabular}

The bearing from Mount St. Helens to the Hanford Waste Treatment Plant is about $80^{\circ}$, which is close to the boundary between E and ENE sectors. These azimuths have the maximum probabilities for most altitude ranges, showing that the prevailing winds blow directly from St. Helens toward the site. From table 2 it is apparent that the mean probabilities change with altitude: they increase to a maximum at the 3-18 km range, then decrease as the upper altitude increases. Which range is most appropriate for this analysis? The maximum height of the sustained plume during St. Helens' 1980 eruption was $19 \mathrm{~km}$ (Harris and others, 1981). The plume created by the initial explosion exceeded $30 \mathrm{~km}$ in height, but the conditions at the volcano that produced this event are no longer present. Plume heights derived from studies of geologically recent tephra deposits at St. Helens range from 11 to $31 \mathrm{~km}$ (Carey and others, 1995). The plume heights of the largest eruptions of Mount Pinatubo in 1991 exceeded the radar ceiling of $24 \mathrm{~km}$, but the height of the climactic eruption was estimated to be about $34 \mathrm{~km}$ on the basis of satellite data (Hoblitt and others, 1996; Koyaguchi and Tokuno, 1993). Plume height increases with VEI magnitude, and VEI 4 and 5 eruptions would be expected to typically produce plume heights at the upper ranges of those in table 2 , that is, the ranges that exhibit decreasing probabilities. However, for this analysis, we shall use $\mathrm{P}(2 \mid 1)=0.180$ - the maximum mean probability in the Hanford sector, as a conservative value. The Hanford sector is a $22.5^{\circ}$ sector centered on an azimuth of $80^{\circ}$, which is the approximate azimuth from Mount St. Helens to Hanford. The maximum mean probability in the Hanford sector is slightly greater than the 0.161 probability derived from the wind analysis in the 1987 report. 


\section{P(3|2): Exceedance Probability of Tephra Accumulation}

To determine the exceedance probability of accumulating a given thickness of tephra at a given point, we require empirical data on distance versus thickness. For the present analysis we will confine our attention to data from VEI 4, VEI 5, and two VEI 5-6 eruptions (Newhall and Hoblitt, 2002; appendix 2). From the global catalog, we only have 14 examples in this VEI range that contain reliable data at the $200 \mathrm{~km}$ distance ( 4 of these are from St. Helens) that is applicable to Hanford. The number of observations is small, chiefly because distal deposits tend to be thin and thin deposits are apt to be poorly preserved. A few millimeters of ash may last no more than a day or two before rain and wind redistribute it. Deposits from prehistoric eruptions are examined centuries to millennia after deposition, reducing the chance of preservation. Even deposits from recent eruptions are usually examined weeks to months after deposition. Because thick deposits are more apt to be preserved than thin deposits, thick deposits are probably over-represented in the dataset.

Most of the tephra deposits in this data set were studied after some degree of compaction. We discuss the implications of this in a later section.

To calculate tephra exceedance probability - the probability that an eruption will deposit tephra whose thickness at a given distance from its source will be greater than or equal to a specified valuewe first rank the empirical observations from highest to lowest, with the greatest value assigned a rank of 1 . The exceedance probability for a thickness value of rank $m$ is $m /(n+1)$, where $n$ is the number of data points. Results for the 14 eruptions with data extending to $200 \mathrm{~km}$ from source are tabulated in table 3 .

Table 3. Exceedance probabilities of tephra accumulations at 200-km distance from source volcano for 14 VEI 4 and 5 eruptions from the global catalog (appendix 2; Newhall and Hoblitt, 2002).

[In cases where thickness is the same for two layers, they are given the mean rank of their positions (for example, the rank of 12.5 is for the two same-thickness layers that occupy ranks 12 and 13); *, four tephra layers from Mount St. Helens]

\begin{tabular}{ccc}
\hline Thickness (cm) & Rank & Exceedance Probability \\
\hline 0.1 & 14 & 0.93 \\
0.2 & 12.5 & 0.83 \\
0.2 & 12.5 & 0.83 \\
1 & 11 & 0.73 \\
$2^{*}$ & 9.5 & 0.63 \\
$2^{*}$ & 9.5 & 0.63 \\
3 & 7.5 & 0.50 \\
3 & 7.5 & 0.50 \\
5 & 5.5 & 0.37 \\
5 & 5.5 & 0.37 \\
$6^{*}$ & 3.5 & 0.23 \\
6 & 3.5 & 0.23 \\
$7.5^{*}$ & 2 & 0.13 \\
10 & 1 & 0.067 \\
\hline
\end{tabular}

\section{$P\left(1\right.$ and 2 and 3): Estimate of Tephra Thickness that would be Equaled or Exceeded at the $1 \times 10^{-4}$ Annual Probability Level}

We use $\mathrm{P}(1$ and 2 and 3$)=\mathrm{P}(1) * \mathrm{P}(2 \mid 1) * \mathrm{P}(3 \mid 2)$ to estimate the tephra thickness that would be equaled or exceeded at the $1 \times 10^{-4}$ level. First we multiply $\mathrm{P}(3 \mid 2)$, the exceedance probability for each thickness in table 3 , by $\mathrm{P}(1) * \mathrm{P}(2 \mid 1)$, that is, by $0.008 * 0.180$. One of three terms - the eruption probability — only has one significant figure. Consequently the resultant annual tephra exceedance 
probabilities are given to one significant figure in table 4 and figure 1 . The tephra thickness that corresponds to an annual exceedance probability of $1 \times 10^{-4}$ is $10 \mathrm{~cm}$.

Table 4. Exceedance probabilities and annual probabilities of exceedance of tephra accumulations at the Hanford Site for the eruption data from table 3.

[The annual exceedance probability is the product of the exceedance probability, the wind probability in the Hanford sector $(0.180$; table 2$)$, and the St. Helens' eruption probability (0.008; table 1$)$. The eruption probability only has one significant figure; consequently the resultant annual exceedance probabilities are given to one significant figure, which results in several lines having the same value.]

\begin{tabular}{ccc}
\hline Thickness (cm) & Exceedance Probability & $\begin{array}{c}\text { Annual Probability } \\
\text { of Exceedance }\end{array}$ \\
\hline & & \\
0.1 & 0.93 & $1 \times 10^{-3}$ \\
0.2 & 0.83 & $1 \times 10^{-3}$ \\
0.2 & 0.83 & $1 \times 10^{-3}$ \\
1 & 0.73 & $1 \times 10^{-3}$ \\
2 & 0.63 & $9 \times 10^{-4}$ \\
2 & 0.63 & $9 \times 10^{-4}$ \\
3 & 0.50 & $7 \times 10^{-4}$ \\
3 & 0.50 & $7 \times 10^{-4}$ \\
5 & 0.37 & $5 \times 10^{-4}$ \\
5 & 0.37 & $5 \times 10^{-4}$ \\
6 & 0.23 & $3 \times 10^{-4}$ \\
6 & 0.23 & $3 \times 10^{-4}$ \\
7.5 & 0.13 & $2 \times 10^{-4}$ \\
10 & 0.067 & $1 \times 10^{-4}$ \\
\hline
\end{tabular}

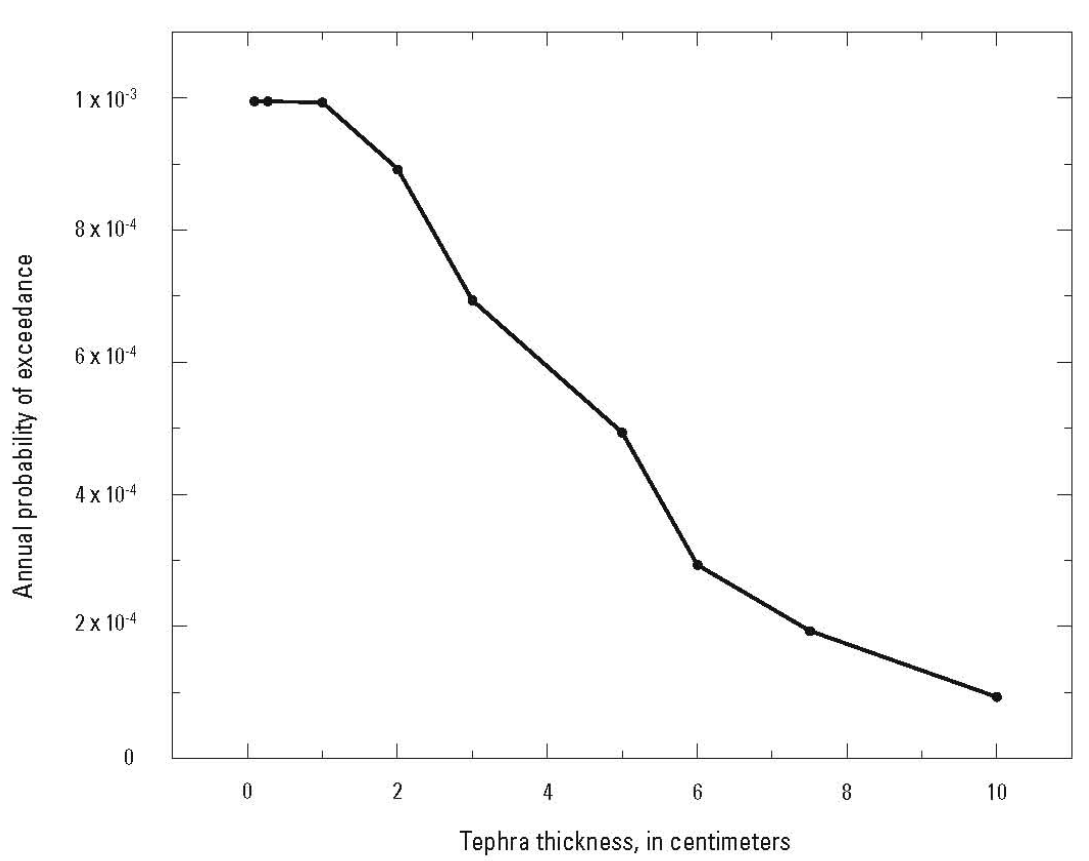

Figure 1. Annual probability of exceedance for various thicknesses of tephra fallout (in centimeters) at the Hanford Site in south-central Washington State. 
Each of the three probabilities used to reach this estimate is conservative. The mean annual eruption probability, based on activity of the past 500 years, is likely an overestimate due to a large explosive eruption just three decades ago. The mean wind direction probability is likely an overestimate, because we chose the altitude range with the highest value. Large eruptions are apt to send tephra to higher altitudes, where the average wind-direction probabilities are lower. The tephra accumulation exceedance probabilities are also likely overestimates because of sampling bias - thin distal deposits tend to be underreported. Consequently the estimated annual probability of equally or exceeding about $10 \mathrm{~cm}$ of tephra at Hanford is likely not greater than $1 \times 10^{-4}$.

Because the deposits used in this analysis are chiefly from prehistoric eruptions or from historical eruptions whose deposits were subject to wetting and some degree of compaction before study, the 10-cm thickness estimated above does not consist of low-density, freshly fallen tephra. Thickness of the May 18, 1980, deposit from Mount St. Helens is the only one of the 14 deposits analyzed that we are certain is uncompacted. In downwind areas, this deposit had an average in-place bulk density of about $450 \mathrm{~kg} / \mathrm{m}^{3}$ (Sarna-Wojicki and others, 1981). Tephra fallout from two smaller eruptions in the summer of 1980 that was compacted during or soon after deposition by rain had average bulk densities of $1,000-1,250 \mathrm{~kg} / \mathrm{m}^{3}$. A similar difference in density was reported for uncompacted and compacted ash-fall deposits from the 1982 eruptions of El Chichón volcano in Mexico (Varecamp and others, 1984), and variably compacted tephra deposits of the 1991 eruption of Pinatubo volcano in the Philippines had a mean bulk density of about $1,000 \mathrm{~kg} / \mathrm{m}^{3}$ (Paladio-Melosantos and others, 1996). Therefore, the 10-cm ash-fall thickness determined for Hanford probably represents a deposit whose dry bulk density would be in the range of $1,000-1,250 \mathrm{~kg} / \mathrm{m}^{3}$, and it would thereby impart an average tephra load of about $100-125 \mathrm{~kg} / \mathrm{m}^{2}$ on horizontal surfaces. Water falling with the tephra or added by later rain or snow would provide additional weight.

\section{Revised Probabilistic Tephra-Fall Map}

Maps showing the annual probability of the accumulation of 1,10 , and 100 centimeters or more of tephra fallout in the northwestern United States from Cascade sources were published in Hoblitt and others (1987), and the 1- and 10-centimeter maps were updated in hazard assessments for Cascade volcanoes published in the mid and late 1990s (for example, Scott and others, 1995). The maps were made from a process similar to that described above in the section on "Probability Analysis." Probabilities were determined for each point in a grid covering the Pacific Northwest for eruptions from all Cascade sources; those probabilities were then contoured. The maps show how Mount St. Helens' frequent and highly explosive eruptions dominate tephra probabilities in the region. In the 1987 map for 10 centimeters or more of tephra, the 0.001 annual-probability contour passed through the Hanford area, whereas in the 1995 map the 0.0002 contour passed through Hanford. This near order-of-magnitude difference resulted chiefly from a labeling error on the 1987 contour lines-values of $0.1 \times 10^{-x}$ were labeled as $1 \times 10^{-\mathrm{x}}$. In retrospect we also found an error in the 1995 analysis in binning of wind data that has been corrected in the present calculations. The 1995 probability contours are displaced outward compared to those from the new calculations use to create figure 2 , and the probability at a given site is about a factor of two higher in the 1995 calculations than in the present work. Two of the published maps (Mount Rainier, Hoblitt and others, 1998; and Mount Hood, Scott and others 1997) also had graphical errors that shifted the volcanoes and contours eastward from their correct positions. 


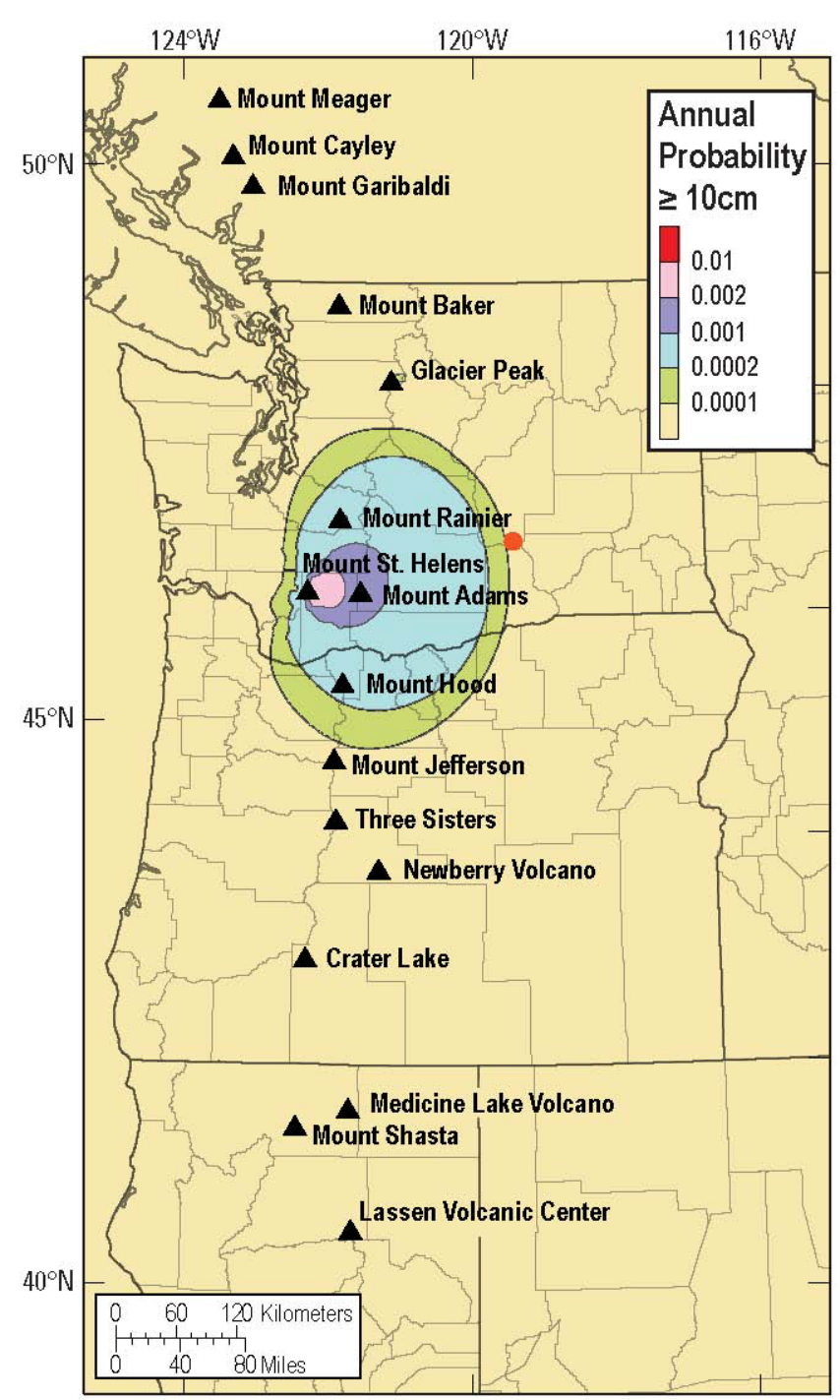

Figure 2. Preliminary probabilistic tephra-hazard map for Pacific Northwest, revised from Hoblitt and others (1987) and Scott and others (1995). Contours show the estimated probability of the accumulation of 10 centimeters or more of tephra from eruptions of the 16 major volcanic centers (black triangles) in the Cascade volcanic arc. Contour pattern accentuates how Mount St. Helens' explosivity and high eruption frequency dominate the probability analysis. Orange dot shows location of Hanford Waste Treatment Plant.

We have corrected these errors in a new version of the map for accumulation of 10 centimeters or more of tephra, which will replace the maps in existing USGS hazard assessments for Cascade volcanoes. On our new map (fig. 2), the 0.0001 contour of annual probability passes slightly west of the Waste Treatment Plant, consistent with the site-specific analysis presented above.

\section{Conclusion}

The tephra accumulation thickness that would be equaled or exceeded at the Hanford Waste Treatment Plant at the $1 \times 10^{-4}$ annual probability level is estimated to be about $10 \mathrm{~cm}$. The values used 
to calculate this estimate are thought to be conservative, and consequently the estimate is considered conservative.

\section{References Cited}

Bacon, C.R., Mastin, L.G., Scott, K.M., and Nathenson, Manuel, 1997, Volcano and earthquake hazards in the Crater Lake region, Oregon: U.S. Geological Survey Open-File Report 97-487, 32 p.

Begét, J.E., 1982, Postglacial volcanic deposits at Glacier Peak, Washington, and potential hazards from future eruptions: U.S. Geological Survey Open-File Report 82-830, 77 p.

Begét, J.E., 1983, Glacier Peak, Washington; a potentially hazardous Cascade volcano: Environmental Geology, v.5, p. 83-92.

Carey, S., Gardner, J., and Sigurdsson, H., 1995, The intensity and magnitude of Holocene plinian eruptions from Mount St. Helens volcano: Journal of Volcanology and Geothermal Research, v. 66, p. 185-202.

Crandell, D.R., and Mullineaux, D.R., 1978, Potential hazards from future eruptions of Mount St. Helens volcano, Washington: U.S. Geological Survey Bulletin 1383-C, 26 p.

Crandell, D.R., Mullineaux, D.R., and Miller, C.D., 1979, Volcanic-hazards studies in the Cascade Range of the western United States, in Sheets, P.D., and Grayson, D.K., eds., Volcanic activity and human ecology: New York, Academic Press, p. 195-219.

Donnelly-Nolan, J.M., Nathenson, Manuel, Champion, D.E., Ramsey, D.W., Lowenstern, J.B., and Ewert, J.W., 2007, Volcano hazards assessment for Medicine Lake volcano, northern California: U.S. Geological Survey Scientific Investigations Report 2007-5174-A, 26 p.

Gardner, J.E., Carey, Steven, and Sigurdsson, Haraldur, 1998, Plinian eruptions at Glacier Peak and Newberry volcanoes, United States - implications for volcanic hazards in the Cascade Range: Geological Society of America Bulletin, v. 110, no. 2, p. 173-187.

Harris, D.M., Rose, W.I., Jr., Roe, Robert, and Thompson, M.R., 1981, in Lipman, P. W., and Mullineaux, D. R., eds., The 1980 eruptions of Mount St. Helens, Washington: U.S. Geological Survey Professional Paper 1250, p. 323-333.

Hildreth, Wes, 2007, Quaternary magmatism in the Cascades - geologic perspectives: U.S. Geological Survey Professional Paper 1744, 125 p.

Hildreth, W., and Fierstein, J., 1997, Recent eruptions of Mount Adams, Washington Cascades, USA: Bulletin of Volcanology, v. 58, p. 472-490.

Hoblitt, R.P., Crandell, D.R., and Mullineaux, D.R., 1980, Mount St. Helens eruptive behavior during the past 1,500 yr: Geology, v. 8, p. 555-559.

Hoblitt, R.P., Scott, W.E., and Miller, C.D., 1987, Volcanic hazards with regard to siting nuclear-power plants in the Pacific Northwest: U.S. Geological Survey Open-File Report 87-297, 196 p.

Hoblitt, R.P., Walder, J.S., Driedger, C.L., Scott, K.M., Pringle, P.T., and Vallance, J.W., 1998, Volcano hazards from Mount Rainier, Washington, revised 1998: U.S. Geological Survey OpenFile Report 98-428, 11 p.

Hoblitt, R.P., Wolfe, E.W., Scott, W.E., Couchman, M.R., Pallister, J.S., and Javier, Dindo, 1996, The preclimactic eruptions, June 1991, Mount Pinatubo, Philippines, in Newhall, C.G. and Punongbayan, R.S., eds., Fire and mud - eruptions and lahars of Mount Pinatubo, Philippines: Quezon City, Philippine Institute of Volcanology and Seismology and Seattle, University of Washington Press, p. 457-511.

Hyde, J.H., and Crandell, D.R., 1978, Postglacial volcanic deposits at Mount Baker, Washington, and potential hazards from future eruptions: U.S. Geological Survey Professional Paper 1022-C, p. $\mathrm{C} 1-\mathrm{C} 17$. 
Koyaguchi, Takehiro, and Tokuno, Masami, 1993, Origin of the giant eruption cloud of Pinatubo, June 15, 1991: Journal of Volcanology and Geothermal research, v. 55, p. 85-96.

Kuehn, S.C., Froese, D.G., Carrara, P.E., Foit, F.F., Jr., Pearce, N.J.G., and Rotheisler, Peter, 2009, Major- and trace-element characterization, expanded distribution, and a new chronology for the latest Pleistocene Glacier Peak tephras in western North America: Quaternary Research, v. 71, p. 201-216.

Mori, Yukihiro, 1986, Evaluation of several "single-pass" estimators of the mean and the standard deviation of wind direction: Journal of Climate and Applied Meteorology, V. 25, 1387-1397.

Mullineaux, D.R., 1996, Pre-1980 tephra-fall deposits erupted from Mount St. Helens, Washington: U.S. Geological Survey Professional Paper 1563, 99 p.

Nathenson, Manuel, Donnelly-Nolan, J.M., Champion, D.E., and Lowenstern, J.B., 2007, Chronology of postglacial eruptive activity and calculation of eruption probabilities for Medicine Lake volcano, northern California: U.S. Geological Survey Scientific Investigations Report 20075174-B, 10 p. http://pubs.usgs.gov/sir/2007/5174/b/

Newhall, C.G. and Hoblitt, R.P., 2002, Constructing event trees for volcanic crises: Bulletin of Volcanology, v. 64, no. 1, p. 3-20.

Newhall, C.G., and Self, Stephen, 1982, The volcanic explosivity index (VEI): an estimate of explosive magnitude for historical volcanism: Journal of Geophysical Research, v. 87, p. 1231-1238.

Paladio-Melosantos, M.L.O., Solidum, R.U., Scott, W.E., Quiambao, R.B., Umbal, J.V., Rodolfo, K.S., Tubianosa, B.S., Delos Reyes, P.J., Alonso, R.A., and Ruelo, H.B., 1996, Tephra falls of the 1991 eruptions of Mount Pinatubo, in Newhall, C.G., and Punongbayan, R.S., eds., Fire and mud - eruptions and lahars of Mount Pinatubo, Philippines: Quezon City, Philippine Institute of Volcanology and Seismology, and Seattle, University of Washington Press, p. 513-535.

Ramsey, D.W., Miller, C.D., and Ewert, J.W., 2009, Preliminary volume estimates of primary Holocene rhyolitic tephras at Medicine Lake volcano, northern California [abs]: Geological Society of America Abstracts with Programs, v. 14, no. 7, p. 63.

Sarna-Wojcicki, A.M., Shipley, Susan, Waitt, R.B., Jr., Dzurisin, Daniel, and Wood, S.H., 1981, Areal distribution, thickness, mass, volume, and grain size of air-fall ash from the six major eruptions of 1980, in Lipman, P.W., and Mullineaux, D.R., eds., The 1980 eruptions of Mount St. Helens, Washington: U.S. Geological Survey Professional Paper 1250, p. 577-600.

Scott, W.E., 1987, Holocene rhyodacite eruptions on the flanks of South Sister volcano, Oregon, in Fink, J.H., ed., The emplacement of silicic domes and lava flows: Geological Society of America Special Paper 212, p. 35-53.

Scott, W.E., 1990, Patterns of volcanism in the Cascade arc during the past 15,000 years: Geoscience Canada, v. 17, p. 179-183.

Scott, W.E., Hoblitt, R.P., Torres, R.C., Self, Stephen, Martinez, M.M., and Nillos, Timotheo, Jr., 1996, Pyroclastic flows of the June 15, 1991, climactic eruption of Mount Pinatubo, in Newhall, C.G., and Punongbayan, R.S., eds., Fire and mud - eruptions and lahars of Mount Pinatubo, Philippines: Quezon City, Philippine Institute of Volcanology and Seismology, and Seattle, University of Washington Press, p. 545-570.

Scott, W.E., Iverson, R.M., Vallance, J.W., and Hildreth, Wes, 1995, Volcano hazards in the Mount Adams region, Washington: U.S. Geological Survey Open-File Report 95-492, 11 p.

Scott, W.E., Pierson, T.C., Schilling, S.P., Costa, J.E., Gardner, C.A., Vallance, J.W., and Major, J.J., 1997, Volcano hazards in the Mount Hood region, Oregon: U.S. Geological Survey Open-File Report 97-89, 14 p. 
Siebert, Lee, Simkin, Tom, and Kimberly, Paul, 2010, Volcanoes of the world ( $3^{\mathrm{d}}$ ed.): Berkeley, University of California Press, $551 \mathrm{p}$.

Sisson, T.W., and Vallance, J.W., 2009, Frequent eruptions of Mount Rainier over the last 2600 years: Bulletin of Volcanology, v. 71, p. 596-618. doi:10.1007/s00445-008-0245-7

Varecamp, J.C., Luhr, J.F., and Prestegaard, K.L., 1984, The 1982 eruptions of El Chichón volcano (Chiapas, Mexico): Character of the eruptions, ash-fall deposits, and gasphase: Journal of Volcanology and Geothermal Research, v. 23, p. 39-68. 


\section{Appendix 1. Discussion of Table 1 Highlighting Differences in Eruptive History Details from Compilations by Hoblitt and Others (1987) and Siebert and Others (2010)}

In table 1 we make minor changes to the values given in Hoblitt and others (1987, table 5-1) for the mean annual probabilities of a substantial $\left(\geq 0.1 \mathrm{~km}^{3}\right)$ tephra eruption at several volcanoes. In addition, table 1 also contains a few differences in the number of $\geq$ VEI 4 (bulk volume of tephra $\geq 0.1$ $\mathrm{km}^{3}$ ) eruptions at several volcanoes compared to data in the Smithsonian Institution's compilation of world volcanism by Siebert and others (2010).

$\circ$ Mount Baker - an eruption about 6,600 years ago, which is listed in Siebert and others (2010) as VEI 3, is included in Hoblitt and others (1987) and in this report as VEI 4 on the basis of its estimated volume of 0.1 to $0.2 \mathrm{~km}^{3}$ (Hyde and Crandell, 1978).

- Glacier Peak-Hoblitt and others (1987) list two large $\left(\geq 0.1 \mathrm{~km}^{3}\right)$ eruptions at the end of the last ice age, but subsequent work by Gardner and others (1998) demonstrates that there were three. We do not include an eruption about $200 \mathrm{CE}$ to which Siebert and others (2010) assign a VEI of 4+. The seminal study of the eruptive history of the volcano (Begét, 1982, 1983) describes the event as a prolonged period of lava-dome growth and collapse rather than a single explosive eruption and notes that only minor tephra has accompanied eruptions of the past 6,000 years. The eruption probability does not change at one significant figure.

- Mount St. Helens - we include three tephra deposits (layers Pu, Ps, and Yd) between 2,500 and 4,000 years old in addition to the Hoblitt and others (1987) list, on the basis of work by Gardner and others (1998). Siebert and others (2010) include all of these save for one of the P layers. These additions do not affect the probability used in the exceedance analysis in this report, which is based on eruptions of the past 500 years.

○ Three Sisters - in agreement with Siebert and others (2010), we add one event at Three Sisters, the Rock Mesa tephra $\left(\sim 0.1 \mathrm{~km}^{3}\right.$; Scott, 1987). The new eruption probability, $8 \mathrm{x}$ $10^{-5}$, is greater than the value in Hoblitt and others (1987), $4 \times 10^{-5}$, estimated from 1 event in the past 25,000 years.

- Medicine Lake volcano-Donnelly-Nolan and others (2007) describe two tephra layers $\geq 0.1 \mathrm{~km}^{3}$, but on the basis of Ramsey and others (2009) we include the Glass Mountain tephra $\left(0.18 \mathrm{~km}^{3}\right)$ but not the Little Glass Mountain tephra $\left(0.06 \mathrm{~km}^{3}\right)$. This results in an increase in the annual eruption probability from $1 \times 10^{-5}$ to $9 \times 10^{-5}$. 


\section{Appendix 2. Tephra Data Used in Estimation of Annual Exceedance Probabilities}

Thickness versus distance data from 14 historical and prehistoric tephra fallout deposits were used to estimate annual exceedance probabilities for tephra accumulation at the Hanford Site in southcentral Washington State. The data are from a compilation by Newhall and Hoblitt (2002) and were selected for this analysis because they have measurements of tephra thickness at $200 \mathrm{~km}$ from vents, the approximate distance of Hanford from Mount St. Helens. Information regarding deposit A from El Chichón was supplemented at distances greater than $40 \mathrm{~km}$ by using observations from Varecamp and others (1984). Except for the May 18, 1980, deposit from Mount St. Helens, all of these thicknesses represent some degree of compaction from the time of deposition to the time of measurement.

\begin{tabular}{|c|c|c|c|c|c|c|c|c|c|c|c|}
\hline Volcano & Date & VEI $^{1}$ & $\begin{array}{c}5 \\
\mathrm{~km}\end{array}$ & $\begin{array}{c}\mathrm{Tr} \\
10 \\
\mathrm{~km} \\
\end{array}$ & $\begin{array}{c}\text { knes } \\
15 \\
\text { km } \\
\end{array}$ & $\begin{array}{c}\text { in } \mathrm{cn} \\
20 \\
\mathrm{~km}\end{array}$ & $\begin{array}{r}\text { at dis } \\
30 \\
\text { km }\end{array}$ & $\begin{array}{c}\text { nce f } \\
40 \\
\text { km }\end{array}$ & $\begin{array}{c}n \text { ven } \\
50 \\
\text { km }\end{array}$ & $\begin{array}{c}\text { in } \mathbf{~ k m}) \\
100 \\
\text { km }\end{array}$ & $\begin{array}{l}200 \\
\text { km }\end{array}$ \\
\hline Agung & May 1963 & 4 & 50 & 30 & 20 & 12 & 8 & 1 & 0.8 & 0.2 & 0.1 \\
\hline Lascar & $\begin{array}{l}1993 \\
\text { 1982; deposit }\end{array}$ & 4 & & 20 & 15 & 8 & 6 & 4 & 3 & 2 & 0.2 \\
\hline El Chichón & A & 4 & 18 & 12 & 9 & 6 & 2 & 1 & 0.8 & 0.4 & 0.2 \\
\hline Soufrière St. Vincent & 1812 & 4 & & & & & & & & 5 & 3 \\
\hline Askja & 1875 & 4 & & 35 & 33 & 30 & 26 & 23 & 20 & 8 & 5 \\
\hline Cosegüina & 1835 & 5 & 60 & 30 & 25 & 20 & 15 & 12 & 10 & 5 & 1 \\
\hline St. Helens Wn & 1480 & 5 & & 150 & 120 & 100 & 50 & 22 & 16 & 5 & 2 \\
\hline St. Helens & May 18,1980 & 5 & 20 & 11 & 11 & 11 & 9 & 7 & 3 & 3 & 2 \\
\hline Usu & $\sim 580 \mathrm{yr}$ ago & 5 & & & & & & & & 20 & 5 \\
\hline Hudson & August 1991 & 5 & & 250 & 225 & 200 & 150 & 80 & 50 & 13 & 6 \\
\hline St. Helens Ye & $\sim 3,500$ yr ago & 5 & & 35 & 32 & 30 & 26 & 23 & 20 & 14 & 7.5 \\
\hline Santa Mariá & 1902 & 5 & & 100 & 84 & 75 & 60 & 50 & 40 & 30 & 10 \\
\hline Pinatubo & June 15,1991 & $5^{2}$ & 40 & 30 & 27 & 25 & 18 & 16 & 14 & 5 & 3 \\
\hline St. Helens Yn & $\sim 3,900 \mathrm{yr}$ ago & $5^{2}$ & 150 & 140 & 120 & 110 & 90 & 80 & 60 & 20 & 6 \\
\hline
\end{tabular}

${ }^{1}$ Volcanic Explosivity Index of Newhall and Self (1982)

${ }^{2}$ Listed as VEI 5 in Newhall and Hoblitt (2002), but as VEI 6 in Siebert and others (2010) 